Prepared in cooperation with the U.S. Department of Energy, National Nuclear Security Administration Nevada Site Office, Office of Environmental Management under Interagency Agreement DE-A152-07NV28100

\title{
Ground-Water Temperature Data, Nevada Test Site and Vicinity, Nye, Clark, and Lincoln Counties, Nevada, 2000-2006
}

Data Series 269 



\title{
Ground-Water Temperature Data, Nevada Test Site and Vicinity, Nye, Clark, and Lincoln Counties, Nevada, 2000-2006
}

\author{
By Steven R. Reiner
}

Prepared in cooperation with the U.S. Department of Energy, National Nuclear Security Administration Nevada Site Office, Office of Environmental Management under Interagency

Agreement DE-A152-07NV28100

Data Series 269 


\title{
U.S. Department of the Interior DIRK KEMPTHORNE, Secretary
}

\author{
U.S. Geological Survey \\ Mark D. Myers, Director
}

\section{U.S. Geological Survey, Reston, Virginia: 2007}

For product and ordering information:

World Wide Web: http://www.usgs.gov/pubprod

Telephone: 1-888-ASK-USGS

For more information on the USGS--the Federal source for science about the Earth, its natural and living resources, natural hazards, and the environment:

World Wide Web: http://www.usgs.gov

Telephone: 1-888-ASK-USGS

Any use of trade, product, or firm names is for descriptive purposes only and does not imply endorsement by the U.S. Government.

Although this report is in the public domain, permission must be secured from the individual copyright owners to reproduce any copyrighted materials contained within this report.

Suggested citation:

Reiner, S.R., 2007, Ground-water temperature data, Nevada Test Site and vicinity, Nye, Clark, and Lincoln Counties, Nevada, 2000-2006: U.S. Geological Survey Data Series 269, 20 p. 


\section{Contents}

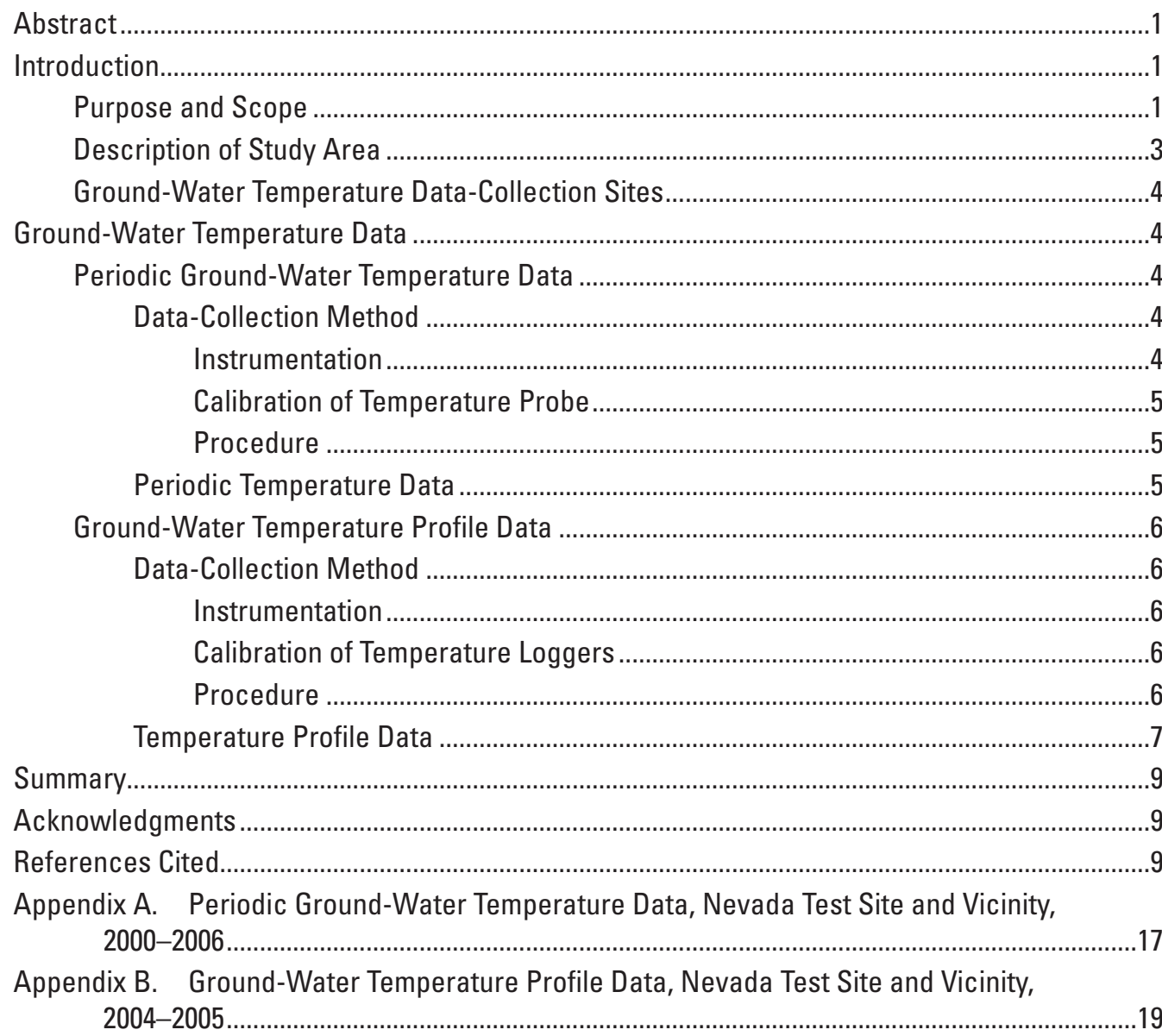

\section{Plate}

Plate 1. Map showing ground-water temperature data-collection sites, Nevada Test Site and vicinity, Nye, Clark, and Lincoln Counties, Nevada, 2000-2006

\section{Figures}

Figure 1. Map showing location of the Nevada Test Site and vicinity, Nevada and California

Figure 2. Graph showing periodic ground-water temperature data, well PM-1 (7543-7858 ft), Nevada Test Site, Nevada, 2000-2006.

Figure 3. Schematic diagram of ground-water temperature profile data-collection equipment

Figure 4. Graphs showing ground-water temperature profile data, well PM-1 (7543-7858 ft), Nevada Test Site, Nevada, November 3, 2004 


\section{Tables}

Table 1. Characteristics of ground-water temperature data-collection sites at and in the vicinity of the Nevada Test Site, Nye, Clark, and Lincoln Counties, Nevada.

\section{Conversion Factors, Datums, Abbreviations and Acronyms}

Conversion Factors

\begin{tabular}{lcl}
\hline Multiply & By & To obtain \\
\hline inch (in.) & 25.4 & millimeter $(\mathrm{mm})$ \\
foot (ft) & 0.3048 & meter $(\mathrm{m})$ \\
mile (mi) & 1.609 & kilometer $(\mathrm{km})$ \\
\hline
\end{tabular}

Temperature in degrees Celsius $\left({ }^{\circ} \mathrm{C}\right)$ may be converted to degrees Fahrenheit $\left({ }^{\circ} \mathrm{F}\right)$ as follows:

$$
{ }^{\circ} \mathrm{F}=\left(1.8 x^{\circ} \mathrm{C}\right)+32
$$

Temperature in degrees Fahrenheit $\left({ }^{\circ} \mathrm{F}\right)$ may be converted to degrees Celsius $\left({ }^{\circ} \mathrm{C}\right)$ as follows:

$$
{ }^{\circ} \mathrm{C}=\left({ }^{\circ} \mathrm{F}-32\right) / 1.8
$$

Datums

Vertical coordinate information is referenced to the National Geodetic Vertical Datum of 1929 (NGVD 29).

Horizontal coordinate information is referenced to the North American Datum of 1983 (NAD 83).

Altitude, as used in this report, refers to distance above the vertical datum.

Abbreviations and Acronyms

\begin{tabular}{ll}
$\begin{array}{c}\text { Abbreviations and } \\
\text { Acronyms }\end{array}$ & \multicolumn{1}{c}{ Definition } \\
\hline CET & Calibrated electric tape \\
DTW & Depth to water \\
DTWR & Depth to water rounded to the nearest foot \\
HP & Hang point \\
MP & Measuring point \\
NIST & National Institute of Standards and Technology \\
NTS & Nevada Test Site \\
UET & Uncalibrated electric tape \\
USDOE & U.S. Department of Energy \\
USGS & U.S. Geological Survey \\
\hline
\end{tabular}




\title{
Ground-Water Temperature Data, Nevada Test Site and Vicinity, Nye, Clark, and Lincoln Counties, Nevada, 2000-2006
}

\author{
By Steven R. Reiner
}

\begin{abstract}
Ground-water temperature data were collected by the U.S. Geological Survey in wells at and in the vicinity of the Nevada Test Site during the years 2000-2006. Periodic ground-water temperatures were collected in 166 wells. In general, periodic ground-water temperatures were measured annually in each well at 5 and 55 feet below the water surface. Ground-water temperature profiles were collected in 73 wells. Temperatures were measured at multiple depths below the water surface to produce these profiles. Databases were constructed to present the ground-water temperature data.
\end{abstract}

\section{Introduction}

The Nevada Test Site (NTS) is located in Nye County, southern Nevada (fig. 1). The NTS was established in 1950 as a continental proving ground for the testing of nuclear weapons and alternative uses of nuclear explosions (U.S. Department of Energy, 2000, p. 48). Atmospheric nuclear testing at or above land surface at the NTS was conducted from 1951 to 1962. Underground nuclear testing at the NTS began in 1951 and continued until a worldwide moratorium on nuclear testing began in 1992. From 1951 to 1992, 828 underground nuclear tests were completed at the NTS (Laczniak and others, 1996, p. 21-22, table 4). Radionuclide contaminants may be introduced to ground water during underground nuclear tests if the depth at which the nuclear device is detonated or the depth of the shock cavity produced by the detonation is below the pre-test water table. Of the 828 underground nuclear tests conducted at the NTS, about 220 were detonated below or near the water table and are considered by Laczniak and others (1996, table 4) certain or probable sources of ground-water contamination.
A long-term program to investigate and remediate radionuclide contaminants generated at the NTS is a mission of the U.S. Department of Energy (USDOE), National Nuclear Security Administration Nevada Site Office, Environmental Restoration Program. Models of the ground-water flow system at and in the vicinity of the NTS are being developed to help the USDOE evaluate the risk that radionuclide contaminants may have on the public and the environment (Waddell, 1982; Belcher, 2004; Stoller-Navarro Joint Venture, 2006a, 2006b). Accurate ground-water temperatures are useful when developing ground-water flow models. Periodic groundwater temperature measurements can be used to detect temporal changes in ground-water temperature. Ground-water temperature depth profiles provide the data needed to correct measured water levels for temperature effects, to evaluate the direction and magnitude of ground-water flow within a well, and to calibrate hydrologic models with temperature targets.

\section{Purpose and Scope}

This report presents ground-water temperature data collected by the U.S. Geological Survey (USGS) at and in the vicinity of the NTS. Periodic ground-water temperatures were measured in 166 wells during calendar years 2000 through 2006 (pl. 1). Generally, periodic ground-water temperatures were measured annually at about 5 and $55 \mathrm{ft}$ below the water surface. Periodic ground-water temperature data are presented in appendix A.

Ground-water temperature profiles were collected in 73 wells during calendar years 2004 and 2005 (pl. 1). Groundwater temperatures were collected on one occasion in each well at multiple depths within the accessible water column. Ground-water temperature profile data are presented in appendix B. 


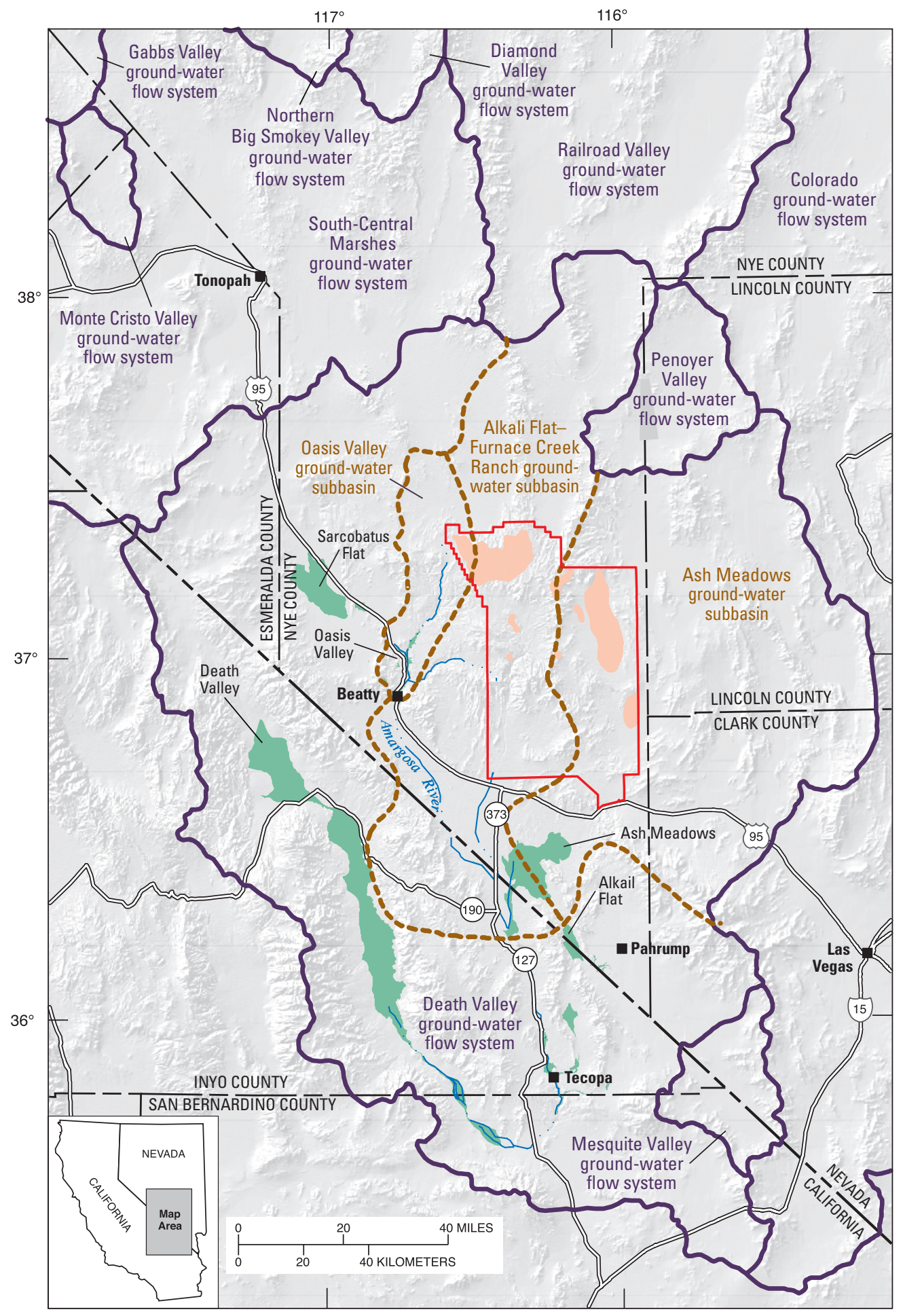

Base from U.S. Geological Survey digital data, 1:100,000, 1978 89: Universal Transverse Mercator Projection Zone 11. Shaded illumination from northwest at 30 degrees above horizon

\section{EXPLANATION}

Discharge areas-Modified after Reiner and others (2002)

Areas of underground nuclear testingModified after Laczniak and others (1996)

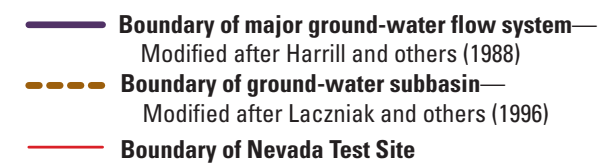

Figure 1. Location of the Nevada Test Site and vicinity, Nevada and California. 


\section{Description of Study Area}

The study area is the NTS and other areas in the vicinity of the NTS. The study area lies within the southern part of the Great Basin, an internally drained subdivision of the Basin and Range physiographic province (Fenneman, 1931). The predominant physiographic features of the Basin and Range are linear mountain ranges separating broad, elongated valleys. North-trending mountain ranges are elevated above the similarly trending sediment-filled valleys along large vertical fault displacements. Precambrian siliclastic and metamorphic rocks, Paleozoic carbonate and siliclastic rocks, and Tertiary volcanic rocks constitute the primary rock type of the hills, ridges, and mountain ranges in the study area. The valleys are filled with unconsolidated clastic sediment and semi-consolidated to consolidated clastic rocks, lacustrine limestone, and interbedded volcanic ash and lava flows (Reiner and others, 2002).

The climate at and in the vicinity of the NTS is arid. Climate information from Air Resources Laboratory, Special Operations and Research Division (2006), is summarized below. Annual precipitation ranges from about $2 \mathrm{in} / \mathrm{yr}$ at low altitudes (Laczniak and others, 1999, p. 7) to about 12 in. at high altitudes (Soule, 2006, p. vi). Precipitation is most common in winter, early spring, and mid-summer. Most precipitation is rain; however, snow is possible from autumn through late spring. Humidity at the NTS is fairly low, ranging from typically less than 35 percent in the summer to 70 percent in the winter. Average daily minimum and maximum temperatures at lower altitudes at the NTS are about $-5^{\circ} \mathrm{C}$ to $15^{\circ} \mathrm{C}$ in the winter and about $15^{\circ} \mathrm{C}$ to $40^{\circ} \mathrm{C}$ in the summer. Average daily minimum and maximum temperatures at high altitudes are about $-5^{\circ} \mathrm{C}$ to $5^{\circ} \mathrm{C}$ in the winter and about $15^{\circ} \mathrm{C}$ to $30^{\circ} \mathrm{C}$ in the summer.

More than 90 percent of the study area is contained within the Death Valley ground-water flow system, one of the major hydrologic subdivisions of the southern Great Basin (fig.1; Harrill and others, 1988, sheet 1). Ground water moves southward from recharge areas in central Nevada through carbonate and volcanic rock aquifers (Laczniak and others, 1996, p. 2). Precipitation at high altitudes along the flow path also recharges the carbonate and volcanic rock aquifers. Within the Death Valley ground-water flow system, ground water flows towards four major areas of surface discharge: Ash Meadows, Oasis Valley, Alkali Flat, and Death Valley (fig. 1). The remainder of the study area is contained within the Railroad Valley and South-Central Marshes ground-water flow systems.

The concept of ground-water subbasins helps explain regional ground-water flow at and in the vicinity of the NTS (fig. 1; Laczniak and others, 1996, p. 16-20). Groundwater subbasin boundaries are determined by the location of recharge and discharge areas, geology, hydraulic gradients, and ground-water chemistry. All ground water at the NTS flows within one of three ground-water subbasins of the Death
Valley ground-water flow system: Ash Meadows, Oasis Valley, and Alkali Flat-Furnace Creek Ranch (fig. 1). Ground water in the vicinity of the NTS may flow either within these groundwater subbasins, in parts of the Death Valley ground-water flow system outside of these subbasins, or outside the Death Valley ground-water flow system. Ground-water levels at and in the vicinity of the NTS range in altitude from about $6,000 \mathrm{ft}$ beneath the Kawich Range to below sea level at Death Valley (Laczniak and others, 1996, p. 16). The ground-water flow system or subbasin where ground-water temperature datacollection sites are located is provided in appendixes $\mathrm{A}$ and $\underline{\mathrm{B}}$.

A hydrogeologic unit is an assemblage of rocks and deposits of varying age, lithology, and structural properties (Laczniak and others, 1996, p. 10; Sweetkind and others, 2004, p. 34). Each hydrogeologic unit has distinct hydrologic properties based on this assemblage. Five significant regional hydrogeologic units are at and in the vicinity of the NTS (Laczniak and others, 1996, p. 10-16). These five regional hydrogeologic units are, from oldest to youngest,

(1) the basement confining unit, (2) the carbonate-rock aquifer, (3) the Eleana confining unit, (4) the volcanic aquifers and confining units, and (5) the valley-fill aquifer.

The basement confining unit is a low-transmissivity confining unit composed of Eocambrian to Cambrian quartzite, micaceous quartzite, and siltstone. This hydrogeologic unit acts as the hydrologic basement for most of the study area.

The carbonate-rock aquifer consists of Cambrian to Devonian dolomite, interbedded limestone, and thin layers of shale and quartzite. Secondary openings from fractures and ground-water dissolution in the carbonate rocks make this regional hydrogeologic unit highly transmissive (Winograd and Thordarson, 1975, p. C74; Dettinger, 1989, p. 5). An upper carbonate-rock aquifer of Pennsylvanian age is in parts of the study area but is not considered a regional hydrogeologic unit. The upper and lower carbonate-rock aquifers are separated from each other by the Eleana confining unit; where the Eleana confining unit is absent, the upper and lower carbonate-rock aquifers act as a single hydrogeologic unit.

The Eleana confining unit, although limited in areal extent, is considered a regional hydrogeologic unit. The unit is low permeability, Mississippian to Devonian age siltstone, sandstone, and conglomerate.

Tertiary age volcanic-rock aquifers and confining units form a regional hydrogeologic unit. Highly fractured, dense volcanic rocks with abundant fractures, such as welded tuffs or lava flows, make up the volcanic aquifers whereas confining units are formed generally by nonwelded tuff that may be zeolitized (Winograd and Thordarson, 1975, p. C44). In general, this hydrogeologic unit forms localized aquifers; however, deep fractured volcanic-rock units may be considered a regional aquifer (Blankennagel and Weir, 1973, p. 6). 
The valley-fill aquifer regional hydrogeologic unit consists of unconsolidated coarse- to fine-grained sediments with localized carbonate, volcanic, and sedimentary rock units (Sweetkind and others, 2004, p. 39-44). Ground-water flow within this unit is dependent on physical properties of the sediment, including grain size and amount of cementation (Belcher and others, 2006). In general, transmissive units within the valley-fill aquifer consist of coarser grained sediments like gravel and sand which, when saturated, may have high porosity and permeability (Laczniak and others, 1996, p. 15). Finer grained sediments, like silt, clay, and fine-grained sand, form confining units within the valley-fill aquifer.

The principal regional hydrogeologic unit contributing water to a well in which ground-water temperatures were measured is provided in appendixes A and $\underline{B}$. Localized granitic stocks of Cretaceous age are not considered a regional hydrogeologic unit (Laczniak and others, 1996, p. 14, 25).

However, granitic stocks are identified in appendixes A and $\underline{B}$ as a hydrogeologic unit when it is the principal rock type contributing water to a well.

Underground nuclear testing at the NTS (fig. 1) can affect local ground-water conditions. Any hydraulic property or water level measured in an underground nuclear test area may not be the same as pre-nuclear testing values (Laczniak and others, 1996, p. 42). Fractures resulting from underground nuclear testing can change aquifer permeability and storage properties. Interstitial fluid pressure in aquifers and groundwater temperature may be affected. Underground nuclear tests have changed water levels for months or years (Garber, 1971, p. C207; Thordarson, 1987, p. 12-16) and may affect groundwater flow rates and direction.

\section{Ground-Water Temperature Data-Collection Sites}

Periodic ground-water temperature data were collected in 166 wells located between latitude 36 and 39 degrees north and longitude 115 and 118 degrees west within Nye, Clark, and Lincoln Counties, Nev. (pl. 1; table 1, at back of report). A well, for the purpose of this report, is a bored, drilled, or dug hole with a depth greater than its largest surface dimension and a discrete open interval (U.S. Environmental Protection Agency, 1997; Fenelon, 2005, p. 6). Temperature data may be collected from multiple wells within a single borehole because each well has a distinct open interval. Ninety-two of the 166 wells at which periodic ground-water temperatures were collected are located within the boundaries of the NTS. About 95 percent of the wells with periodic ground-water temperature data are located in the Death Valley ground-water flow system (fig. 1). The remaining 5 percent are located either in the Railroad Valley or South-Central Marshes ground-water flow systems.
Ground-water temperature profiles were collected in 73 wells located between latitude 36 and 38 degrees north and longitude 115 and 117 degrees west within Nye County, Nev. (pl. 1; table 1). Of the 73 wells in which groundwater temperature profiles were collected, 52 are located within the NTS boundaries and 21 are located outside the NTS boundaries. Forty-one of the wells with ground-water temperature profile data are in the Ash Meadows ground-water subbasin, 16 are in the Oasis Valley ground-water subbasin, and 16 are in the Alkali-Flat-Furnace Creek Ranch groundwater subbasin.

All wells in which ground-water temperatures were measured are part of a USGS water-level monitoring network. This network is supported by the USDOE National Nuclear Security Administration Nevada Site Office, Environmental Restoration Program.

\section{Ground-Water Temperature Data}

Data presented for each well consist of depth-to-water measurements, depth below water level where ground-water temperature was measured, and ground-water temperature. Distances are reported in inch-pound units (feet) and temperatures in degrees Celsius.

\section{Periodic Ground-Water Temperature Data}

\section{Data-Collection Method}

Periodic ground-water temperature data were collected with a temperature probe attached to the end of a calibrated electric tape. In general, temperatures in each well were measured annually at depths of 5 and $55 \mathrm{ft}$ below the water surface. If necessitated by well conditions, the depths of ground-water temperature measurements were varied.

\section{Instrumentation}

A temperature probe was used to collect periodic ground-water temperature data. The temperature probe protects a thermistor in which electrical resistance varies with temperature. The probe can be used to depths of $1,500 \mathrm{ft}$ below the water surface and has a temperature range of $-5^{\circ} \mathrm{C}$ to $50^{\circ} \mathrm{C}$ (Solinst Canada Ltd., 1995).

The temperature probe was attached to the bottom of a calibrated electric tape. A calibrated electric tape also was used to measure depth to water prior to temperature data collection. The calibrated electric tape measurements are considered accurate to within $0.1 \mathrm{ft}$. 


\section{Calibration of Temperature Probe}

The temperature probe was calibrated annually. The calibration procedure begins by determining the "before" resistance of an electric tape without a temperature probe. The temperature probe is then attached to the electric tape and placed into a water-filled container. Measurements of the resistance of electric tape plus the resistance of the temperature probe thermistor are recorded at various water temperatures ranging from about $0^{\circ} \mathrm{C}$ to $50^{\circ} \mathrm{C}$. During the procedure, water temperature is determined using a National Institute of Standards and Technology (NIST)-calibrated thermometer. After all measurements of the resistance of the electric tape plus the resistance of the thermistor are completed, the "after" resistance of the electric tape without the temperature probe is again measured. The average resistance of the electric tape is the average of the "before" and "after" measurements of electric tape resistance. The average resistance of the electric tape is subtracted from the resistance of the electric tape plus the resistance of the thermistor to determine the resistance of the thermistor at various water temperatures. An equation is used to convert the resistance of the thermistor to a temperature. A regression or best-fit line is fitted to thermistor-derived temperatures versus calibrated thermometer temperatures. The equation of the bestfit line is then used to adjust field-measured temperatures to a calibrated temperature.

\section{Procedure}

The general steps used for collecting periodic groundwater temperature data at 5 and $55 \mathrm{ft}$ below the water surface are as follows:

1. Depth to water below measuring point (DTW) for the well is measured using a calibrated electric tape (CET). No correction factor is applied to the measurement. The DTW is then rounded to the nearest foot and recorded as the rounded depth to water below measuring point (DTWR).

2. A "before" resistance for a CET is measured before the temperature probe is attached to the CET.

3. The CET is lowered into the well to the depth at which the temperature probe would be $5 \mathrm{ft}$ below the DTWR. The resistance of the CET plus the resistance of the temperature probe thermistor is recorded.

4. The CET is lowered into the well to the depth at which the temperature probe would be $55 \mathrm{ft}$ below the DTWR. The resistance of the CET plus the resistance of the temperature probe thermistor is recorded. The CET is removed from the well.

5. The temperature probe is removed from the CET and an "after" resistance for CET is measured.

\section{Periodic Temperature Data}

Periodic ground-water temperature data collected in the field were processed using a Microsoft ${ }^{\circledR}$ Excel spreadsheet. The "before" and "after" measured resistances of the electric tape were averaged to determine an average electric tape resistance. The average electric tape resistance was subtracted from the resistance of the electric tape plus the resistance of the temperature probe thermistor to determine the resistance of the thermistor while submerged below water within the well. A raw water temperature is calculated from the resistance of the submerged thermistor. The raw water temperature is corrected for the temperature probe calibration to determine a final calibrated water temperature. Based on data-collection methods, periodic ground-water temperatures are considered accurate to within $1^{\circ} \mathrm{C}$.

A table of periodic ground-water temperature measurements collected during calendar years 2000-2006 in 166 wells at and in the vicinity of the NTS is presented in appendix A. The appendix provides information on site location, well construction, hydrogeologic unit, depths-towater, and temperature data for each of the wells.

Periodic ground-water temperatures measured in wells at and in the vicinity of the NTS ranged from about $10.7^{\circ} \mathrm{C}$ to $50.4^{\circ} \mathrm{C}$. The minimum temperature was measured in well TTR Antelope Mine 1 at $11 \mathrm{ft}$ below land surface and the maximum in well ER- 3-1-2 (shallow) at $55 \mathrm{ft}$ below land surface. An example of the results from periodic ground-water temperature collection is shown in figure 2.

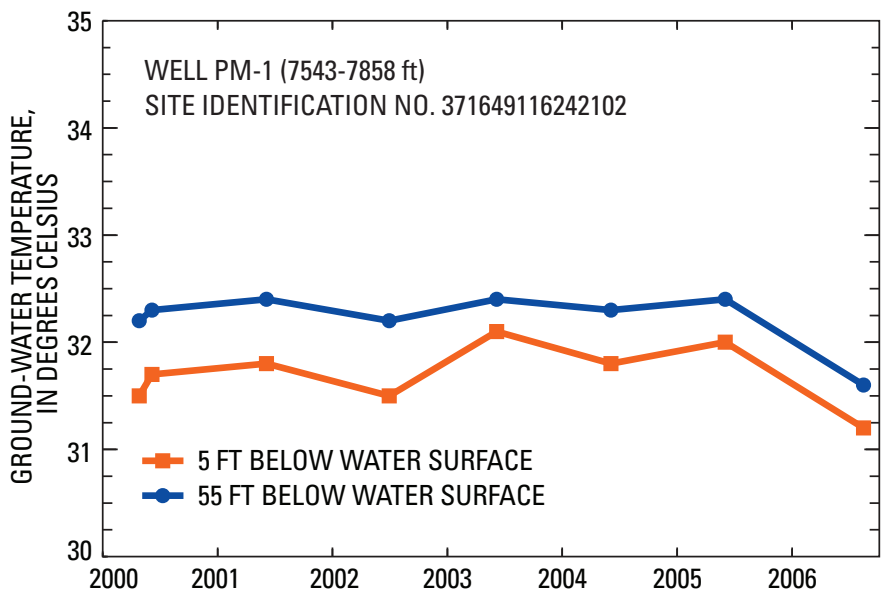

Figure 2. Periodic ground-water temperature data, well PM-1 (7543-7858 ft), Nevada Test Site, Nevada, 2000-2006. 


\section{Ground-Water Temperature Profile Data}

\section{Data-Collection Method}

Ground-water temperature profile data were collected with temperature loggers attached to an electric tape. Temperatures were collected at multiple depths throughout the water column.

\section{Instrumentation}

Sealed underwater temperature loggers were used to collect ground-water temperature profile data. The loggers were depth rated to $1,000 \mathrm{ft}$, but have been known to work at pressures equivalent to $10,000 \mathrm{ft}$ of water (Onset Computer Corporation, 1996). The temperature range of the loggers is $-20^{\circ} \mathrm{C}$ to $50^{\circ} \mathrm{C}$, but they will record temperatures as much as $70^{\circ} \mathrm{C}$.

The sealed temperature loggers were attached to an uncalibrated electric tape at 20 -ft intervals. The tape was believed to be accurate to at least the nearest foot based upon its previous use as a calibrated electric tape. This accuracy was sufficient for the ground-water temperature profiles.

Calibrated electric tapes were used to measure depth to water prior to temperature-data collection. The calibrated electric tape measurements are recorded as being accurate to within $0.1 \mathrm{ft}$.

\section{Calibration of Temperature Loggers}

Prior to field use, temperature loggers were checked for accuracy, precision, resolution, and the time needed to equilibrate to surrounding fluid temperature. To evaluate accuracy, precision, and resolution, multiple temperature loggers were activated and submerged into a container of water. The water was stabilized at various temperatures within the range of temperatures expected to be encountered in the field. Temperature loggers were allowed to equilibrate at these stable temperatures for at least 10 minutes. The accuracy of an individual logger was determined by comparing its recorded temperatures with temperatures from an NIST-calibrated thermometer. The precision of an individual logger was determined by comparing its recorded temperatures with the recorded temperatures from other loggers. The resolution of an individual logger was determined by noting the minimum difference between temperature readings that each logger could record. Each logger has 255 different temperature steps in its measurement range that can be recorded (Onset Computer Corporation, 1996).

The accuracy, precision, and resolution of the loggers are temperature dependent. The measured accuracies of the temperature loggers, which are the differences between logger temperature readings and measurements from an NISTcalibrated thermometer, range from $\pm 0.2^{\circ} \mathrm{C}$ to $\pm 0.7^{\circ} \mathrm{C}$. The measured accuracies are within $\pm 0.3^{\circ} \mathrm{C}$ of the manufacturer's specifications of $\pm 0.4^{\circ} \mathrm{C}$ from $0^{\circ} \mathrm{C}$ to about $30^{\circ} \mathrm{C}$ and $\pm 0.5^{\circ} \mathrm{C}$ from about $30^{\circ} \mathrm{C}$ to $50^{\circ} \mathrm{C}$.
The temperature logger precisions, which are the maximum differences between temperatures measured simultaneously by multiple loggers, are between $0.3^{\circ} \mathrm{C}$ and $0.6^{\circ} \mathrm{C}$. Measured resolutions are within $0.1^{\circ} \mathrm{C}$ of manufacturer's resolution specifications of $\pm 0.3^{\circ} \mathrm{C}$ from about $0^{\circ} \mathrm{C}$ to $25^{\circ} \mathrm{C}$ and $\pm 0.4^{\circ} \mathrm{C}$ from $25^{\circ} \mathrm{C}$ to $50^{\circ} \mathrm{C}$.

Based on data-collection methods and the accuracy, precision, and resolution testing, ground-water temperature profile measurements between $0.5^{\circ} \mathrm{C}$ and $50^{\circ} \mathrm{C}$ are considered accurate to within $1^{\circ} \mathrm{C}$. Temperatures measured greater than $50^{\circ} \mathrm{C}$ may be less accurate.

The equilibration time needed for the loggers to record a consistent temperature was measured. Temperature loggers were quickly moved from a container of relatively cold, warm, or hot water and placed into a container with water of different temperature. The amount of time the logger needed to equilibrate after these changes was recorded. Equilibration times ranged from 7 to 16 minutes. Equilibration times when temperature changes were less abrupt were as short as 2 minutes.

\section{Procedure}

The general steps used for collecting ground-water temperature profile data are as follows (fig. 3 ):

1. Prior to data collection, the temperature loggers are attached to an uncalibrated electric tape (UET). The temperature loggers are spaced at 20 -ft intervals with the initial logger to enter the well located $5 \mathrm{ft}$ above the bottom of the UET and the final logger to enter the well located $185 \mathrm{ft}$ above the bottom of the UET.

2. DTW for the well is measured using a calibrated electric tape. No correction factor is applied to the measurement. The DTW value is then rounded to the nearest foot and recorded as the DTWR.

3. The length of water column is estimated by subtracting the DTWR from the most recent measured accessible well depth. The length of the water column is needed to estimate the length of UET that will be lowered into the well or borehole.

4. The UET is lowered into the well. Each temperature logger is activated and time synchronized before being lowered into the well.

- If the estimated water column length is less than 200 $\mathrm{ft}$, the UET is lowered to the maximum accessible depth of the well. The UET is then raised so that the nearest whole number foot marking on the UET above that accessible depth lines up with the measuring point (MP). The whole number foot marking is recorded as the hang point (HP). 

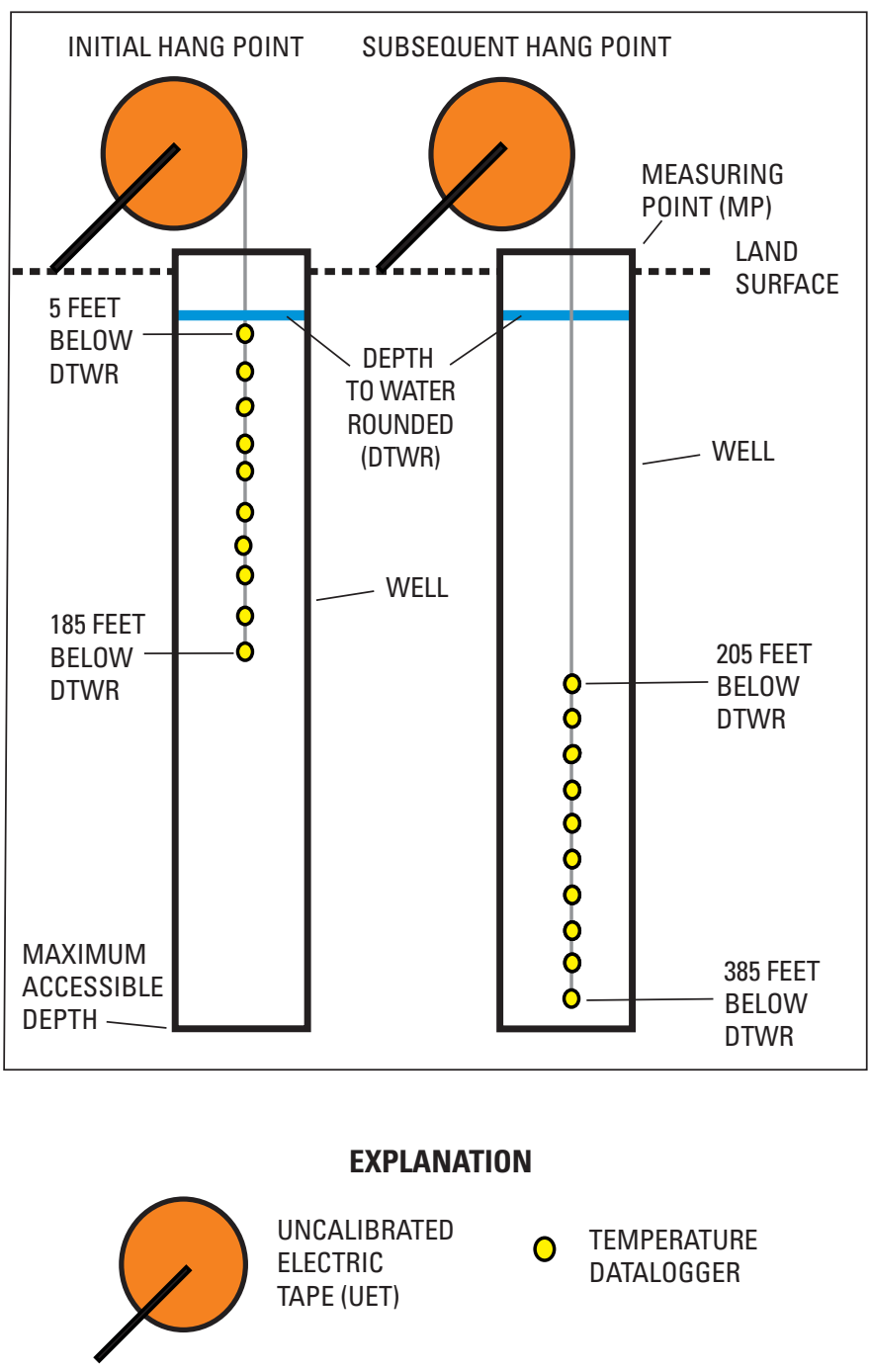

O TEMPERATURE
DATALOGGER

Figure 3. Ground-water temperature profile data-collection equipment.

- If the estimated water column length is equal to or greater than $200 \mathrm{ft}$, the UET is lowered to a HP such that the temperature logger located $185 \mathrm{ft}$ above the bottom of the UET will be $5 \mathrm{ft}$ below DTWR and the temperature logger located $5 \mathrm{ft}$ above the bottom of UET will be $185 \mathrm{ft}$ below DTWR (fig. 3). If the maximum accessible depth is reached before the temperature loggers are located at these depths, then the procedures used for an estimated column length of less than $200 \mathrm{ft}$ should be used.

5. The UET is secured at the HP and a start time recorded. The UET is not moved from the HP for at least 10 minutes to allow the temperature loggers to equilibrate to the surrounding water temperature. Before the UET is moved, an end time is recorded.
6. The UET is moved to a different HP.

- If the water column length was determined in step 4 to be less than $200 \mathrm{ft}$, the UET is moved so that one temperature logger measures ground-water temperature about $5 \mathrm{ft}$ below the water surface. Other temperatures will be measured in 20-ft intervals below the logger at $5 \mathrm{ft}$ below the water surface.

- If the water column length was determined in step 4 to be equal to or greater than $200 \mathrm{ft}$, the UET is lowered so that the HP is $200 \mathrm{ft}$ greater than in step 4 (fig. 3). If a maximum accessible depth is reached before the HP is lowered the additional $200 \mathrm{ft}$, then the UET is raised so that the nearest whole number foot marking on the UET above that maximum accessible depth lines up with the MP.

7. The UET is secured at the HP and a start time recorded. The UET is not moved from the HP for at least 8 minutes to allow the temperature loggers to equilibrate to the surrounding water temperature. Before the UET is moved, an end time is recorded.

8. In wells that have not reached maximum accessible depth by the end of step 7, steps 6 and 7 are repeated until maximum accessible depth is reached in the well, or the UET has been extended to its maximum length.

9. The UET is raised out of the well. Data is collected from each temperature logger. Each temperature logger is then deactivated.

\section{Temperature Profile Data}

Temperature profile data collected in the field were processed using a Microsoft $®$ Excel spreadsheet. The spreadsheet used the HP, data collection times at each HP, and the position of the logger on the UET to determine the depth of each logger below the water surface and the temperature at that depth (K.J. Halford, U.S. Geological Survey, written commun., 2004). Temperature correction factors only slightly affected temperature logger readings and were not applied to these values.

A table of the ground-water temperature profiles collected in 73 wells at and in the vicinity of the NTS is presented in appendix B. The appendix provides information on site location, well construction, hydrogeologic unit, depths-to-water, and temperature data. Two graphs of temperature versus depth below land surface for each well with temperature profiles greater than $50 \mathrm{ft}$ in length also are presented in appendix B. The scale chosen for one of these graphs is customized for each well to illustrate detailed changes in temperature with depth. The scale chosen for the other 
graph is standardized for all wells to illustrate the relative temperature profile length and change in temperature at each well when compared to all collected temperature profiles. An example of the ground-water temperature profile graphs is shown in figure 4.
Temperatures measured while collecting ground-water temperature profiles in wells at and in the vicinity of the NTS during the period of record ranged from about $18.8^{\circ} \mathrm{C}$ to $59.0^{\circ} \mathrm{C}$. The minimum temperature was measured in wells ER- 2-1 piezometer (deep) and UE- 4t 1 (1906-2010 ft) at $5 \mathrm{ft}$ below land surface and the maximum in well PM-1 at 3,565 ft

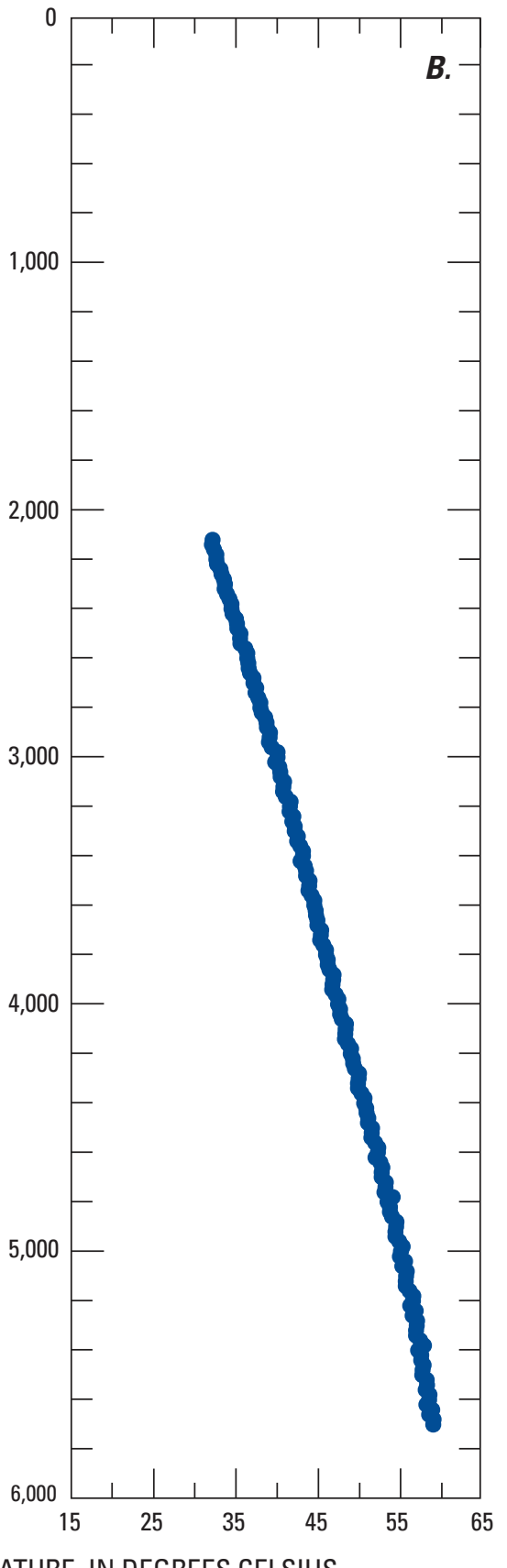

Figure 4. Ground-water temperature profile data, well PM-1 (7543-7858 ft), Nevada Test Site, Nevada, November 3, 2004. The scale chosen for graph A is customized for this well to illustrate detailed changes in temperature with depth. The scale chosen for graph B is standardized to illustrate the relative temperature profile length and change in temperature of this profile when compared to all collected ground-water temperature profiles. 
below land surface. The deepest temperature measurement was at 3,982 ft below land surface and the longest groundwater temperature profile was 3,977 ft.

When available, ground-water temperature profile measurements in a well were compared to periodic temperature measurements closest in depth and measurement date in the same well. The ground-water temperature profile measurements were collected at or within $10 \mathrm{ft}$ of the periodic measurements and, except in three cases, within 400 days. The maximum difference between temperature profile and periodic temperature measurements at similar depths was $1.1^{\circ} \mathrm{C}$, but was less than $0.5^{\circ} \mathrm{C}$ in about 90 percent of the compared measurements.

\section{Summary}

Periodic ground-water temperature data and groundwater temperature profiles were collected in wells at and in the vicinity of the Nevada Test Site (NTS) during the years 2000 through 2006. Periodic ground-water temperatures were collected in 166 wells at and in the vicinity of the NTS. In general, these periodic ground-water temperatures were measured at about 5 and $55 \mathrm{ft}$ below the water surface. Periodic ground-water temperatures are measured using a calibrated temperature probe attached to the bottom of a calibrated electric tape. Depth measurements are considered accurate to the nearest foot and temperatures are considered accurate to the nearest degree Celsius.

Ground-water temperature profiles were measured in 73 wells at and in the vicinity of the NTS. Temperature loggers attached to an uncalibrated electric tape recorded temperatures at multiple depths below the water surface to produce these profiles. Depth measurements are considered accurate to the nearest foot and temperature measurements accurate to the nearest degree Celsius. The deepest temperature measurement was measured at 3,982 ft below land surface. Differences between periodic and ground-water temperature profile measurements at similar depths were typically less than $0.5^{\circ} \mathrm{C}$.

\section{Acknowledgments}

This study was prepared in cooperation with the U.S. Department of Energy under Interagency Agreement DEAI52-07NV28100. Special thanks to USGS employees Gary Otto and Terry Miller, who collected all ground-water temperature data. Thanks to Peggy Elliott (USGS) for entering the majority of the periodic ground-water temperature data into databases and performing quality assurance. Thanks also to USGS employees Joseph Fenelon, Keith Halford, and Randell Laczniak for writing spreadsheets used to process field data and general guidance in the compilation and basic interpretation of data.

\section{References Cited}

Air Resources Laboratory, Special Operations and Research Division, 2006, Overview of the climate of the Nevada Test Site: National Oceanic and Atmospheric Administration, accessed December 26, 2006, at http://www.sord.nv.doe. gov/climate/climate.nts.general.pdf.

Belcher, W.R., 2004, ed., Death Valley regional groundwater flow system, Nevada and California-hydrogeologic framework and transient ground-water flow model: U.S. Geological Survey Scientific Investigations Report 2004-5205, 408 p.

Belcher, W.R., Faunt, C.C., Sweetkind, D.S., Blainey, J.B., San Juan, C.A., Laczniak, R.J., and Hill, M.C., 2006, Ground-water modeling of the Death Valley Region, Nevada and California: U.S. Geological Survey Fact Sheet 2006-3120, 6 p.

Blankennagel, R.K., and Weir, J.E., Jr., 1973, Geohydrology of the eastern part of Pahute Mesa, Nevada Test Site, Nye County, Nevada: U.S. Geological Survey Professional Paper 712-B, 35 p.

Dettinger, M.D., 1989, Distribution of carbonate-rock aquifers in southern Nevada and the potential for their development-Summary of findings, 1985-1988: Carson City, Nev., Program for the Study and Testing of CarbonateRock Aquifers in Eastern and Southern Nevada, Summary report No. 1, $37 \mathrm{p}$

Fenelon, J.M., 2005, Analysis of ground-water levels and associated trends in Yucca Flat, Nevada Test Site, Nye County, Nevada, 1951-2003: U.S. Geological Survey Scientific Investigations Report 2005-5175, 97 p.

Fenneman, N.M., 1931, Physiography of the Western United States: New York, McGraw-Hill Book Co., 534 p.

Garber, M.S., 1971, A method for estimating effective porosity in a rubble chimney formed by an underground nuclear explosion, in U.S. Geological Survey Research 1971: U.S. Geological Survey Professional Paper 750-C, p. C207C209.

Harrill, J.R., Gates, J.S., and Thomas, J.M., 1988, Major ground-water flow systems in the Great Basin region of Nevada, Utah, and adjacent states: U.S. Geological Survey Hydrologic Investigations Atlas HA-694-C, 2 sheets, scale $1: 1,000,000$.

Laczniak, R.J., Cole, J.C., Sawyer, D.A., and Trudeau, D.A., 1996, Summary of hydrogeologic controls on ground-water flow at the Nevada Test Site, Nye County, Nevada: U.S. Geological Survey Water-Resources Investigations Report 96-4109, 59 p. 
Laczniak, R.J., DeMeo, G.A., Reiner, S.R., Smith, J.L., and Nylund, W.E., 1999, Estimates of ground-water discharge as determined from measurements of evapotranspiration, Ash Meadows area, Nye County, Nevada: U.S. Geological Survey Water-Resources Investigations Report 99-4079, $70 \mathrm{p}$.

Onset Computer Corporation, 1996, Stowaway®TidbiT User's Manual, accessed December 26, 2006, at http://www. onsetcomp.com/support/manual pdfs/loggers/3050 H MAN_TBI32.pdf.

Reiner, S.R., Laczniak, R.J., DeMeo, G.A., Smith, J.L., Elliott, P.E., Nylund, W.E., and Fridrich, C.J., 2002, Ground-water discharge determined from measurements of evapotranspiration, other available hydrologic components, and shallow water-level changes, Oasis Valley, Nye County, Nevada: U.S. Geological Survey Water-Resources Investigations Report 01-4239, 65 p.

Solinst Canada Ltd., 1995, Conductivity and Temperature Profiler Model 101/C4-T4, accessed December 26, 2006, at http://www.solinst.com/Prod/Data/101C4.pdf.

Soule, D.A., 2006, Climatology of the Nevada Test Site: National Oceanic and Atmospheric Administration, Air Resources Laboratory - Special Operation and Research Division, Technical Memorandum SORD 2006-03, 165 p.

Stoller-Navarro Joint Venture, 2006a, Phase II ground-water flow model of Corrective Action Unit 98-Frenchman Flat, Nevada Test Site, Nye County, Nevada: Stoller-Navarro Joint Venture Report S-N/99205-074 prepared for the U.S. Department of Energy, various pagination, accessed February 8, 2007, at http://www.osti.gov/bridge.
Stoller-Navarro Joint Venture, 2006b, Ground-water flow model of Corrective Action Units 101 and 102-Central and Western Pahute Mesa, Nye County, Nevada: StollerNavarro Joint Venture Report S-N/99205-076 prepared for the U.S. Department of Energy, various pagination.

Sweetkind, D.S., Belcher, W.R., Faunt, C.C., and Potter, C.J., 2004, Chapter B. Geology and hydrogeology in Belcher, W.R., 2004, ed., Death Valley regional ground-water flow system, Nevada and California-hydrogeologic framework and transient ground-water flow model: U.S. Geological Survey Scientific Investigations Report 2004-5205, 408 p.

Thordarson, William, 1987, Hydrogeology of the Faultless Site, Nye County, Nevada: U.S. Geological Survey WaterResources Investigations Report 86-4342, 40 p.

U.S. Department of Energy, 2000, Origins of the Nevada Test Site: U.S. Department of Energy DOE/MA-0518, 95 p.

U.S. Environmental Protection Agency, 1997, Terms of environment-glossary, abbreviations, and acronyms: U.S. Environmental Protection Agency EPA\# 175-B-97001, accessed October 2, 2006, at http://www.epa.gov/ OCEPAterms/wterms.html.

Waddell, R.K., 1982, Two-dimensional, steady-state model of ground-water flow, Nevada Test Site and vicinity, NevadaCalifornia: U.S. Geological Survey Water-Resources Investigations Report 82-4085, 77 p.

Winograd, I.J., and Thordarson, William, 1975, Hydrogeologic and hydrochemical framework, south-central Great Basin, Nevada-California, with special reference to the Nevada Test Site: U.S. Geological Survey Professional Paper 712-C, 126 p. 
Table 1. Characteristics of ground-water temperature data-collection sites at and in the vicinity of the Nevada Test Site, Nye, Clark, and Lincoln Counties, Nevada.

[USGS site identification No.: The U.S. Geological Survey (USGS) site identification number. Each site is identified by a unique 15-digit number based on the original latitude-longitude of the site. The first six digits denote degrees, minutes, and seconds of latitude; the next seven digits denote degrees, minutes, and seconds of longitude; and the last two digits are the sequence number of the well within the 1-second grid of latitude and longitude. The assigned number is retained as a permanent identifier even if a more precise latitude and longitude are later determined. To determine the geographic location of a well, the latitude and longitude coordinates should be used rather than the site identifier. Latitude and Longitude: In decimal degrees; referenced to the North American Datum of 1983 (NAD 83). Land-surface altitude: Altitude is in feet above or below the National Geodetic Vertical Datum of 1929 (NGVD 1929). Depth drilled: Total depth to which the hole was drilled, in feet below land surface. Well depth: Accessible depth of the well, in feet below land surface. Well depths are obtained from drilling records or field measurements. Open interval: Depth range, in feet below land surface, within the well where, if surrounding lithologic units are saturated, ground water may enter. The open interval of the well may be openings in the casing and (or) uncased borehole. When more than one open interval occurs in a well, depths are in feet below land surface to the top of the uppermost opening and the bottom of the lowermost opening. Hydrogeologic unit: Principal hydrogeologic unit contributing water to the well. B, basement confining unit; C, carbonate-rock aquifer; F, valley-fill aquifer; S, Eleana confining unit; V, volcanic-rock aquifers and confining units; X, other (granitic stocks). Ground-water flow system or subbasin: The ground-water flow system or, when defined, ground-water subbasin where the well is located. Ground-water subbasins are subdivisions of the Death Valley ground-water flow system (Laczniak and others, 1996). AFFCR, Alkali Flat-Furnace Creek Ranch ground-water subbasin; AM, Ash Meadows ground-water subbasin; DTVSU, Death Valley ground-water flow system, undivided; OV, Oasis Valley ground-water subbasin; RDVSU, Railroad Valley ground-water flow system, undivided; SCMU, South-Central Marshes ground-water flow system, undivided. Available ground-water temperature data: Periodic, periodic ground-water temperature measurements available; Profile, periodic ground-water temperature and ground-water temperature profile measurements available. Abbreviations: -, unknown]

\begin{tabular}{|c|c|c|c|c|c|c|c|c|c|c|c|}
\hline \multirow[b]{2}{*}{$\begin{array}{c}\text { USGS site } \\
\text { identification No. }\end{array}$} & \multirow[b]{2}{*}{$\begin{array}{l}\text { USGS local } \\
\text { site name }\end{array}$} & \multirow[b]{2}{*}{ Latitude } & \multirow[b]{2}{*}{ Longitude } & \multirow{2}{*}{$\begin{array}{l}\text { Land- } \\
\text { surface } \\
\text { altitude }\end{array}$} & \multirow[b]{2}{*}{$\begin{array}{l}\text { Depth } \\
\text { drilled }\end{array}$} & \multirow[b]{2}{*}{$\begin{array}{l}\text { Well } \\
\text { depth }\end{array}$} & \multicolumn{2}{|c|}{ Open interval } & \multirow{2}{*}{$\begin{array}{c}\text { Hydro- } \\
\text { geologic } \\
\text { unit }\end{array}$} & \multirow{2}{*}{$\begin{array}{c}\text { Ground- } \\
\text { water flow } \\
\text { system or } \\
\text { subbasin }\end{array}$} & \multirow{2}{*}{$\begin{array}{c}\text { Available } \\
\text { ground-wate } \\
\text { temperature } \\
\text { data }\end{array}$} \\
\hline & & & & & & & $\begin{array}{l}\text { Depth to } \\
\text { top }\end{array}$ & $\begin{array}{c}\text { Depth to } \\
\text { bottom }\end{array}$ & & & \\
\hline 362936116153001 & Amargosa Flat Playa Well & 36.493 & 116.259 & 2,322 & 15 & 15 & 9 & 14 & $\mathrm{~F}$ & $\mathrm{AM}$ & Periodic \\
\hline 363255115515801 & Army 2 & 36.548 & 115.867 & 3,813 & 658 & 627 & 6 & 658 & $\mathrm{~F}$ & $\mathrm{AM}$ & Periodic \\
\hline 363238115464601 & Army 3 & 36.544 & 115.780 & 3,617 & 826 & 826 & 310 & 826 & $\mathrm{~V}$ & $\mathrm{AM}$ & Periodic \\
\hline 363437116010801 & Army 6A & 36.577 & 116.020 & 3,445 & 1,253 & 1,253 & 1,157 & 1,228 & B & $\mathrm{AM}$ & Periodic \\
\hline 364329116402901 & Ash-B Deep Well & 36.726 & 116.676 & 2,677 & 1,220 & 1,214 & 1,062 & 1,185 & $\mathrm{~V}$ & AFFCR & Periodic \\
\hline 364329116402902 & Ash-B Shallow Well & 36.726 & 116.676 & 2,677 & 1,220 & 457 & 362 & 428 & $\mathrm{~F}$ & AFFCR & Periodic \\
\hline 371309117074901 & BC-1 & 37.219 & 117.131 & 4,001 & 410 & 410 & 339 & 410 & $\mathrm{~V}$ & DTVSU & Periodic \\
\hline 371309117074902 & BC-2 & 37.217 & 117.130 & 4,000 & 125 & 103 & 63 & 103 & $\mathrm{~V}$ & DTVSU & Periodic \\
\hline 365640116431501 & Beatty Wash Terrace Well & 36.944 & 116.722 & 3,460 & 75 & 39 & 55 & 75 & - & OV & Periodic \\
\hline 361515116100901 & BLM Stewart Valley Well & 36.254 & 116.170 & 2,469 & 69 & 69 & - & - & - & DTVSU & Periodic \\
\hline 363422115433701 & Cactus Springs 3 & 36.573 & 115.728 & 3,265 & 100 & 100 & 83 & 100 & - & $\mathrm{AM}$ & Periodic \\
\hline 370725116033901 & ER- 2-1 main (shallow) & 37.125 & 116.063 & 4,216 & 2,600 & 2,079 & 1,642 & 2,177 & $\mathrm{~V}$ & $\mathrm{AM}$ & Profile \\
\hline 370725116033902 & $\begin{array}{l}\text { ER- 2-1 piezometer } \\
\text { (deep) }\end{array}$ & 37.125 & 116.063 & 4,216 & 2,600 & 2,559 & 2,313 & 2,600 & V & $\mathrm{AM}$ & Profile \\
\hline 370116115561302 & ER-3-1-2 (shallow) & 37.019 & 115.937 & 4,407 & 2,807 & 2,310 & 2,208 & 2,310 & $\mathrm{C}$ & $\mathrm{AM}$ & Periodic \\
\hline 370214116021002 & ER- 3-2-2 (middle) & 37.037 & 116.037 & 4,010 & 3,000 & 2,655 & 2,588 & 2,636 & $\mathrm{~F}$ & $\mathrm{AM}$ & Profile \\
\hline 365223115561702 & ER-5-3 deep piezometer & 36.873 & 115.939 & 3,334 & 2,606 & 2,212 & 1,995 & 2,235 & $\mathrm{~F}$ & $\mathrm{AM}$ & Profile \\
\hline 365223115561701 & $\begin{array}{l}\text { ER- 5-3 main (upper } \\
\text { zone) }\end{array}$ & 36.873 & 115.939 & 3,334 & 2,606 & 1,890 & 1,446 & 1,782 & $\mathrm{~F}$ & $\mathrm{AM}$ & Profile \\
\hline 365223115561703 & $\begin{array}{l}\text { ER- 5-3 shallow } \\
\text { piezometer }\end{array}$ & 36.873 & 115.939 & 3,334 & 2,606 & 1,237 & 105 & 1,048 & $\mathrm{~F}$ & $\mathrm{AM}$ & Profile \\
\hline 365223115561801 & ER- 5-3-2 & 36.873 & 115.939 & 3,334 & 5,683 & 4,908 & 4,674 & 5,683 & $\mathrm{C}$ & $\mathrm{AM}$ & Profile \\
\hline 365223115561704 & ER- 5-3-3 & 36.873 & 115.939 & 3,335 & 1,800 & 1,745 & 1,412 & 1,800 & $\mathrm{~F}$ & $\mathrm{AM}$ & Profile \\
\hline 364928115574801 & ER 5-4 main & 36.824 & 115.964 & 3,132 & 3,732 & 3,438 & 1,715 & 3,732 & $\mathrm{~F}$ & $\mathrm{AM}$ & Profile \\
\hline 364928115574802 & ER 5-4 piezometer & 36.824 & 115.964 & 3,132 & 3,732 & 814 & 119 & 813 & $\mathrm{~F}$ & $\mathrm{AM}$ & Profile \\
\hline 364927115574801 & ER 5-4-2 & 36.824 & 115.964 & 3,132 & 7,000 & 6,658 & 4,850 & 7,000 & $\mathrm{~V}$ & $\mathrm{AM}$ & Periodic \\
\hline 365904115593405 & ER-6-1 main (2243 ft) & 36.984 & 115.994 & 3,937 & 3,206 & 2,243 & 1,819 & 2,243 & $\mathrm{C}$ & $\mathrm{AM}$ & Periodic \\
\hline
\end{tabular}


Table 1. Characteristics of ground-water temperature data-collection sites at and in the vicinity of the Nevada Test Site, Nye, Clark, and Lincoln Counties, Nevada.-Continued

\begin{tabular}{|c|c|c|c|c|c|c|c|c|c|c|c|}
\hline \multirow[b]{2}{*}{$\begin{array}{c}\text { USGS site } \\
\text { identification No. }\end{array}$} & \multirow[b]{2}{*}{$\begin{array}{l}\text { USGS local } \\
\text { site name }\end{array}$} & \multirow[b]{2}{*}{ Latitude } & \multirow[b]{2}{*}{ Longitude } & \multirow[b]{2}{*}{$\begin{array}{l}\text { Land- } \\
\text { surface } \\
\text { altitude }\end{array}$} & \multirow[b]{2}{*}{$\begin{array}{l}\text { Depth } \\
\text { drilled }\end{array}$} & \multirow[b]{2}{*}{$\begin{array}{l}\text { Well } \\
\text { depth }\end{array}$} & \multicolumn{2}{|c|}{ Open interval } & \multirow[b]{2}{*}{$\begin{array}{l}\text { Hydro- } \\
\text { geologic } \\
\text { unit }\end{array}$} & \multirow{2}{*}{$\begin{array}{l}\text { Ground- } \\
\text { water flow } \\
\text { system or } \\
\text { subbasin }\end{array}$} & \multirow{2}{*}{$\begin{array}{c}\text { Available } \\
\text { ground-water } \\
\text { temperature } \\
\text { data }\end{array}$} \\
\hline & & & & & & & $\begin{array}{l}\text { Depth to } \\
\text { top }\end{array}$ & $\begin{array}{l}\text { Depth to } \\
\text { bottom }\end{array}$ & & & \\
\hline 365904115593401 & ER- 6-1 main $(3206 \mathrm{ft})$ & 36.984 & 115.994 & 3,937 & 3,206 & 3,045 & 1,819 & 3,206 & $\mathrm{C}$ & $\mathrm{AM}$ & Profile \\
\hline 365904115593403 & ER- 6-1 piezometer & 36.984 & 115.994 & 3,937 & 2,129 & 1,790 & 1,435 & 1,542 & $\mathrm{~V}$ & AM & Periodic \\
\hline 365904115593402 & ER- 6-1-1 & 36.984 & 115.994 & 3,937 & 2,085 & 1,940 & 1,835 & 2,052 & $\mathrm{C}$ & $\mathrm{AM}$ & Profile \\
\hline 365901115593501 & ER- 6-1-2 main & 36.984 & 115.994 & 3,935 & 3,200 & 3,070 & 1,775 & 3,200 & $\mathrm{C}$ & $\mathrm{AM}$ & Profile \\
\hline 365901115593502 & ER- 6-1-2 piezometer & 36.984 & 115.994 & 3,935 & 3,200 & 1,587 & 120 & 1,587 & $\mathrm{~V}$ & $\mathrm{AM}$ & Profile \\
\hline 365740116043501 & ER- 6-2 & 36.961 & 116.077 & 4,231 & 3,430 & 3,408 & 1,746 & 3,430 & $\mathrm{C}$ & $\mathrm{AM}$ & Profile \\
\hline 370424115594301 & ER-7-1 & 37.073 & 115.996 & 4,246 & 2,500 & 2,500 & 1,775 & 2,500 & $\mathrm{C}$ & $\mathrm{AM}$ & Periodic \\
\hline 371106116110401 & ER-12-1 (1641-1846ft) & 37.185 & 116.185 & 5,817 & 3,588 & 3,434 & 1,641 & 1,846 & $\mathrm{C}$ & $\mathrm{AM}$ & Profile \\
\hline 371019116072102 & $\begin{array}{l}\text { ER-12-2 main (lower } \\
\text { zone) }\end{array}$ & 37.171 & 116.123 & 4,705 & 6,883 & 6,883 & 5,203 & 6,883 & S & $\mathrm{AM}$ & Profile \\
\hline 371019116072103 & $\begin{array}{l}\text { ER-12-2 main (upper } \\
\text { zone) }\end{array}$ & 37.171 & 116.123 & 4,705 & 6,883 & 5,203 & 2,964 & 5,203 & S & $\mathrm{AM}$ & Profile \\
\hline 371019116072104 & ER-12-2 piezometer & 37.171 & 116.123 & 4,705 & 6,883 & 579 & 120 & 650 & V & $\mathrm{AM}$ & Profile \\
\hline 371142116125101 & ER-12-3 piezometer & 37.195 & 116.215 & 7,391 & 4,908 & 1,532 & 55 & 2,210 & V & AFFCR & Periodic \\
\hline 371311116105902 & ER-12-4 main & 37.220 & 116.184 & 6,884 & 3,715 & 3,713 & 2,501 & 3,715 & $\mathrm{C}$ & $\mathrm{AM}$ & Periodic \\
\hline 371311116105901 & ER-12-4 piezometer & 37.220 & 116.184 & 6,884 & 3,715 & 1,968 & 56 & 1,988 & $\mathrm{~V}$ & $\mathrm{AM}$ & Periodic \\
\hline 370615116222401 & ER-18-2 & 37.104 & 116.374 & 5,437 & 2,500 & 2,143 & 1,351 & 2,500 & V & AFFCR & Profile \\
\hline 371043116142101 & ER-19-1-1 (deep) & 37.178 & 116.240 & 6,140 & 3,595 & 3,578 & 3,210 & 3,560 & S & AFFCR & Profile \\
\hline 371043116142102 & ER-19-1-2 (middle) & 37.178 & 116.240 & 6,140 & 3,595 & 2,720 & 2,550 & 2,738 & $\mathrm{~V}$ & AFFCR & Profile \\
\hline 371043116142103 & ER-19-1-3 (shallow) & 37.178 & 116.240 & 6,140 & 3,595 & 1,381 & 1,301 & 1,422 & V & AFFCR & Periodic \\
\hline 371321116292301 & ER-20-1 & 37.222 & 116.492 & 6,181 & 2,065 & 2,065 & 1,940 & 2,065 & $\mathrm{~V}$ & AFFCR & Profile \\
\hline 371246116240101 & ER-20-2-1 & 37.213 & 116.401 & 6,705 & 2,524 & 2,494 & 2,293 & 2,524 & $\mathrm{~V}$ & AFFCR & Profile \\
\hline 371537116251501 & ER-20-6-1 (3-in string) & 37.260 & 116.422 & 6,475 & 3,200 & 2,930 & 2,437 & 2,947 & V & AFFCR & Periodic \\
\hline 371536116251601 & ER-20-6-2 (3-in string) & 37.260 & 116.422 & 6,475 & 3,200 & 2,933 & 2,414 & 2,945 & $\mathrm{~V}$ & AFFCR & Periodic \\
\hline 371533116251801 & ER-20-6-3 (3-in string) & 37.259 & 116.422 & 6,466 & 3,200 & 2,790 & 2,436 & 2,807 & V & AFFCR & Periodic \\
\hline 371223116314701 & ER-EC-1 & 37.206 & 116.531 & 6,026 & 5,000 & 4,791 & 2,258 & 4,895 & $\mathrm{~V}$ & OV & Profile \\
\hline 370852116340502 & ER-EC-2a (1635-2236ft) & 37.145 & 116.568 & 4,902 & 4,974 & 2,450 & 1,635 & 2,236 & $\mathrm{~V}$ & OV & Profile \\
\hline 370852116340501 & ER-EC-2a (1635-4973ft) & 37.145 & 116.568 & 4,902 & 4,974 & 4,961 & 1,635 & 4,974 & $\mathrm{~V}$ & OV & Periodic \\
\hline 370935116375302 & ER-EC-4 (952-2295ft) & 37.159 & 116.632 & 4,760 & 3,487 & 2,365 & 952 & 2,296 & $\mathrm{~V}$ & OV & Profile \\
\hline 370935116375301 & ER-EC-4 (952-3487 ft) & 37.159 & 116.632 & 4,760 & 3,487 & 3,445 & 952 & 3,487 & V & OV & Periodic \\
\hline 370504116335201 & ER-EC-5 & 37.084 & 116.565 & 5,077 & 2,500 & 2,449 & 1,169 & 2,500 & V & AFFCR & Profile \\
\hline 371120116294802 & ER-EC-6 (1581-3820 ft) & 37.189 & 116.498 & 5,604 & 5,000 & 4,302 & 1,581 & 3,820 & V & AFFCR & Profile \\
\hline 365910116284401 & ER-EC-7 & 36.985 & 116.479 & 4,805 & 1,386 & 1,304 & 890 & 1,386 & V & AFFCR & Profile \\
\hline 370610116375301 & ER-EC-8 & 37.103 & 116.632 & 4,334 & 2,000 & 1,950 & 632 & 2,000 & $\mathrm{~V}$ & OV & Profile \\
\hline 370504116404901 & ER-OV-01 & 37.084 & 116.681 & 4,073 & 180 & 180 & 150 & 170 & V & OV & Profile \\
\hline 370210116421501 & ER-OV-02 & 37.036 & 116.705 & 3,880 & 200 & 200 & 170 & 190 & $\mathrm{~F}$ & OV & Profile \\
\hline 365956116421601 & ER-OV-03a & 36.999 & 116.705 & 3,844 & 251 & 251 & 220 & 240 & $\mathrm{~V}$ & OV & Profile \\
\hline 365956116421602 & ER-OV-03a2 & 36.999 & 116.705 & 3,844 & 821 & 642 & 602 & 622 & $\mathrm{~V}$ & OV & Profile \\
\hline
\end{tabular}


Table 1. Characteristics of ground-water temperature data-collection sites at and in the vicinity of the Nevada Test Site, Nye, Clark, and Lincoln Counties, Nevada.-Continued

\begin{tabular}{|c|c|c|c|c|c|c|c|c|c|c|c|}
\hline \multirow[b]{2}{*}{$\begin{array}{c}\text { USGS site } \\
\text { identification No. }\end{array}$} & \multirow[b]{2}{*}{$\begin{array}{l}\text { USGS local } \\
\text { site name }\end{array}$} & \multirow[b]{2}{*}{ Latitude } & \multirow[b]{2}{*}{ Longitude } & \multirow[b]{2}{*}{$\begin{array}{l}\text { Land- } \\
\text { surface } \\
\text { altitude }\end{array}$} & \multirow[b]{2}{*}{$\begin{array}{l}\text { Depth } \\
\text { drilled }\end{array}$} & \multirow[b]{2}{*}{$\begin{array}{l}\text { Well } \\
\text { depth }\end{array}$} & \multicolumn{2}{|c|}{ Open interval } & \multirow[b]{2}{*}{$\begin{array}{c}\text { Hydro- } \\
\text { geologic } \\
\text { unit }\end{array}$} & \multirow{2}{*}{$\begin{array}{c}\text { Ground- } \\
\text { water flow } \\
\text { system or } \\
\text { subbasin }\end{array}$} & \multirow{2}{*}{$\begin{array}{c}\text { Available } \\
\text { ground-wate } \\
\text { temperature } \\
\text { data }\end{array}$} \\
\hline & & & & & & & $\begin{array}{l}\text { Depth to } \\
\text { top }\end{array}$ & $\begin{array}{l}\text { Depth to } \\
\text { bottom }\end{array}$ & & & \\
\hline 365956116421603 & ER-OV-03a3 & 36.999 & 116.705 & 3,844 & 821 & 133 & 113 & 133 & $\mathrm{~V}$ & OV & Profile \\
\hline 370139116390501 & ER-OV-03b & 37.027 & 116.652 & 4,233 & 400 & 395 & 353 & 373 & $\mathrm{~F}$ & OV & Profile \\
\hline 365948116360401 & ER-OV-03c & 36.997 & 116.602 & 4,192 & 542 & 542 & 512 & 532 & $\mathrm{~V}$ & AFFCR & Profile \\
\hline 365948116360402 & ER-OV-03c2 & 36.997 & 116.602 & 4,192 & 321 & 321 & 292 & 312 & $\mathrm{~V}$ & AFFCR & Profile \\
\hline 365705116424201 & ER-OV-04a & 36.951 & 116.713 & 3,491 & 151 & 151 & 111 & 131 & $\mathrm{~F}$ & OV & Profile \\
\hline 370246116461901 & ER-OV-05 & 37.046 & 116.773 & 3,938 & 200 & 200 & 170 & 190 & $\mathrm{~F}$ & $\mathrm{OV}$ & Profile \\
\hline 370504116404902 & ER-OV-06a & 37.084 & 116.681 & 4,073 & 536 & 536 & 506 & 526 & V & OV & Profile \\
\hline 370504116404903 & ER-OV-06a2 & 37.084 & 116.681 & 4,073 & 71 & 65 & 56 & 65 & V & OV & Profile \\
\hline 373228116472001 & Hammel Mine Well & 37.541 & 116.790 & 5,540 & - & 123 & - & - & - & DTVSU & Periodic \\
\hline 383734116124501 & HTH-1 & 38.626 & 116.213 & 6,011 & 3,704 & 3,695 & 150 & 3,665 & $\mathrm{~V}$ & RDVSU & Periodic \\
\hline 383023116012201 & HTH-23 & 38.506 & 116.024 & 5,797 & 7,503 & 6,445 & 4,510 & 7,503 & - & RDVSU & Periodic \\
\hline 363317116270801 & LWS-A Deep Well & 36.555 & 116.453 & 2,396 & 2,025 & 1,859 & 1,706 & 1,827 & $\mathrm{~F}$ & AFFCR & Periodic \\
\hline 363317116270802 & LWS-A Shallow Well & 36.555 & 116.453 & 2,396 & 2,025 & 312 & 212 & 278 & $\mathrm{~F}$ & AFFCR & Periodic \\
\hline 365253116450801 & Narrows South Well 2 & 36.881 & 116.753 & 3,180 & 120 & 120 & 20 & 120 & $\mathrm{~F}$ & AFFCR & Periodic \\
\hline 370753116502701 & NDOT TPJ-2 & 37.131 & 116.842 & 4,005 & - & - & - & - & - & DTVSU & Periodic \\
\hline 371649116242102 & PM- 1 (7543-7858ft) & 37.280 & 116.407 & 6,558 & 7,858 & 7,731 & 7,543 & 7,858 & $\mathrm{~V}$ & AFFCR & Profile \\
\hline 372042116340501 & PM- 2 & 37.345 & 116.569 & 5,592 & 8,788 & 8,788 & 2,506 & 8,788 & $\mathrm{~V}$ & OV & Periodic \\
\hline 371421116333703 & PM- 3-1 (1919-2144ft) & 37.239 & 116.561 & 5,823 & 3,019 & 2,145 & 1,872 & 2,192 & $\mathrm{~V}$ & OV & Profile \\
\hline 371421116333704 & PM- 3-2 (1442-1667ft) & 37.239 & 116.561 & 5,823 & 3,019 & 1,667 & 1,379 & 1,687 & $\mathrm{~V}$ & OV & Profile \\
\hline 375533116580601 & Ralston Valley Well & 37.926 & 116.969 & 5,219 & - & - & - & - & - & SCMU & Periodic \\
\hline 373320117090601 & Ralston Well & 37.555 & 117.152 & 4,756 & - & 409 & - & - & - & DTVSU & Periodic \\
\hline 364928115580101 & RNM-1 & 36.824 & 115.968 & 3,135 & 1,302 & 999 & 120 & 999 & $\mathrm{~F}$ & $\mathrm{AM}$ & Periodic \\
\hline 364923115575701 & RNM-2 & 36.823 & 115.967 & 3,129 & 935 & 825 & 118 & 935 & $\mathrm{~F}$ & $\mathrm{AM}$ & Profile \\
\hline 364922115580101 & RNM-2S & 36.823 & 115.968 & 3,130 & 1,156 & 1,120 & 118 & 1,156 & $\mathrm{~F}$ & $\mathrm{AM}$ & Periodic \\
\hline 371615117053601 & SF-1 & 37.271 & 117.094 & 4,022 & 899 & 879 & 839 & 879 & V & DTVSU & Periodic \\
\hline 371615117053602 & SF-2 & 37.271 & 117.094 & 4,021 & 496 & 496 & 456 & 496 & $\mathrm{~F}$ & DTVSU & Periodic \\
\hline 363905116005801 & SM-23-1 & 36.651 & 116.017 & 3,543 & 1,338 & 1,332 & 1,298 & 1,338 & $\mathrm{C}$ & $\mathrm{AM}$ & Periodic \\
\hline 362521116160801 & Spring Meadows 11 & 36.422 & 116.270 & 2,442 & 215 & 215 & - & - & - & $\mathrm{AM}$ & Periodic \\
\hline 370131116440801 & Springdale Upper Well & 37.025 & 116.736 & 3,775 & - & 91 & - & - & - & OV & Periodic \\
\hline 375045116460201 & TTR 3A WW & 37.846 & 116.768 & 5,362 & 805 & 805 & 537 & 805 & - & SCMU & Periodic \\
\hline 375055116460201 & TTR 3BB & 37.849 & 116.768 & 5,358 & - & - & - & - & - & SCMU & Periodic \\
\hline 373622116434601 & TTR Antelope Mine 1 & 37.606 & 116.730 & 6,350 & - & - & - & - & - & DTVSU & Periodic \\
\hline 373622116434701 & TTR Antelope Mine 2 & 37.606 & 116.730 & 6,356 & - & - & - & - & - & DTVSU & Periodic \\
\hline 373623116434701 & TTR Antelope Mine 3 & 37.606 & 116.730 & 6,362 & - & - & - & - & - & DTVSU & Periodic \\
\hline 374619116435401 & TTR EH-4 & 37.771 & 116.734 & 5,458 & 743 & 490 & 150 & 490 & - & DTVSU & Periodic \\
\hline 375139116460001 & TTR EH-6 & 37.861 & 116.767 & 5,355 & 535 & 535 & 0 & 310 & - & SCMU & Periodic \\
\hline 375453116450501 & TTR Reeds Ranch Well & 37.915 & 116.752 & 5,384 & - & 127 & - & - & - & SCMU & Periodic \\
\hline 374725116452701 & TTR Sandia 2 & 37.790 & 116.758 & 5,478 & 525 & 525 & 325 & 485 & - & DTVSU & Periodic \\
\hline 374739116453401 & TTR Sandia 4 & 37.794 & 116.760 & 5,468 & 580 & 580 & 351 & 466 & - & DTVSU & Periodic \\
\hline 374959116431301 & TTR Sandia 5 & 37.833 & 116.721 & 5,334 & 300 & 300 & - & - & - & DTVSU & Periodic \\
\hline
\end{tabular}


Table 1. Characteristics of ground-water temperature data-collection sites at and in the vicinity of the Nevada Test Site, Nye, Clark, and Lincoln Counties, Nevada.-Continued

\begin{tabular}{|c|c|c|c|c|c|c|c|c|c|c|c|}
\hline \multirow[b]{2}{*}{$\begin{array}{c}\text { USGS site } \\
\text { identification No. }\end{array}$} & \multirow[b]{2}{*}{$\begin{array}{l}\text { USGS local } \\
\text { site name }\end{array}$} & \multirow[b]{2}{*}{ Latitude } & \multirow[b]{2}{*}{ Longitude } & \multirow{2}{*}{$\begin{array}{l}\text { Land- } \\
\text { surface } \\
\text { altitude }\end{array}$} & \multirow[b]{2}{*}{$\begin{array}{l}\text { Depth } \\
\text { drilled }\end{array}$} & \multirow[b]{2}{*}{$\begin{array}{l}\text { Well } \\
\text { depth }\end{array}$} & \multicolumn{2}{|c|}{ Open interval } & \multirow{2}{*}{$\begin{array}{c}\text { Hydro- } \\
\text { geologic } \\
\text { unit }\end{array}$} & \multirow{2}{*}{$\begin{array}{l}\text { Ground- } \\
\text { water flow } \\
\text { system or } \\
\text { subbasin }\end{array}$} & \multirow{2}{*}{$\begin{array}{c}\text { Available } \\
\text { ground-water } \\
\text { temperature } \\
\text { data }\end{array}$} \\
\hline & & & & & & & $\begin{array}{l}\text { Depth to } \\
\text { top }\end{array}$ & $\begin{array}{l}\text { Depth to } \\
\text { bottom }\end{array}$ & & & \\
\hline 373446116433301 & TTR Sulfide Mine & 37.579 & 116.727 & 6,130 & - & - & - & - & - & DTVSU & Periodic \\
\hline 370929116132311 & TW- 1 (1615-4206 ft) & 37.158 & 116.224 & 6,156 & 4,206 & 3,694 & 1,615 & 4,206 & $\mathrm{~V}$ & AFFCR & Profile \\
\hline 370353116020201 & TW- 7 & 37.065 & 116.035 & 4,058 & 2,272 & 2,239 & 41 & 2,272 & $\mathrm{~V}$ & $\mathrm{AM}$ & Profile \\
\hline 365849116002101 & TW- B & 36.979 & 116.015 & 3,932 & 1,675 & 1,670 & 1,432 & 1,675 & V & $\mathrm{AM}$ & Profile \\
\hline 370418116044501 & TW- D & 37.074 & 116.076 & 4,150 & 1,950 & 1,950 & 1,700 & 1,950 & $\mathrm{C}$ & $\mathrm{AM}$ & Profile \\
\hline 364534116065902 & TW- F (3400 ft) & 36.759 & 116.117 & 4,143 & 3,392 & 3,392 & 3,142 & 3,392 & $\mathrm{C}$ & $\mathrm{AM}$ & Periodic \\
\hline 370720116041601 & $\mathrm{U}-2 \mathrm{gk}$ & 37.122 & 116.072 & 4,242 & 1,809 & 1,802 & 116 & 1,809 & $\mathrm{~F}$ & $\mathrm{AM}$ & Periodic \\
\hline 370320116012001 & $\mathrm{U}-3 \mathrm{cn} 5$ & 37.059 & 116.023 & 4,009 & 3,030 & 2,830 & 2,832 & 3,030 & $\mathrm{C}$ & $\mathrm{AM}$ & Profile \\
\hline 370020115593001 & $\mathrm{U}-3 \mathrm{mi}$ & 37.006 & 115.993 & 4,006 & 1,794 & 1,651 & 372 & 1,794 & V & $\mathrm{AM}$ & Profile \\
\hline 370451116024101 & $\mathrm{U}-7 \mathrm{~cd}$ & 37.081 & 116.046 & 4,115 & 1,625 & 1,523 & 117 & 1,625 & $\mathrm{~V}$ & $\mathrm{AM}$ & Periodic \\
\hline 371342116125102 & $\mathrm{U}-12 \mathrm{~s}(1480 \mathrm{ft})$ & 37.228 & 116.217 & 6,794 & 1,596 & 1,467 & 12 & 1,480 & $\mathrm{X}$ & AFFCR & Periodic \\
\hline 371346116032601 & U- 15k Test Hole & 37.229 & 116.058 & 5,168 & 857 & 857 & 404 & 857 & $\mathrm{X}$ & $\mathrm{AM}$ & Profile \\
\hline 371349116222001 & $\mathrm{U}-19 \mathrm{bh}$ & 37.230 & 116.373 & 6,768 & 2,148 & 2,107 & 72 & 2,148 & $\mathrm{~V}$ & AFFCR & Periodic \\
\hline 371736116184701 & $\mathrm{U}-19 \mathrm{bj}$ & 37.293 & 116.314 & 7,035 & 2,153 & 2,149 & 57 & 2,153 & $\mathrm{~V}$ & AFFCR & Periodic \\
\hline 371714116230301 & $\mathrm{U}-19 \mathrm{bk}$ & 37.287 & 116.385 & 6,670 & 2,198 & 2,192 & 57 & 2,198 & $\mathrm{~V}$ & AFFCR & Profile \\
\hline 371505116254501 & U -20 WW (cased) & 37.251 & 116.430 & 6,468 & 3,268 & 3,268 & 65 & 3,268 & $\mathrm{~V}$ & AFFCR & Periodic \\
\hline 371414116242901 & $\mathrm{U}-20 \mathrm{bg}$ & 37.237 & 116.409 & 6,567 & 2,200 & 2,200 & 58 & 2,200 & $\mathrm{~V}$ & AFFCR & Periodic \\
\hline 383806116125951 & UC-1-P-2SR & 38.635 & 116.216 & 6,084 & 3,600 & 2,734 & 1,148 & 2,790 & - & RDVSU & Periodic \\
\hline 370254116070601 & UE- 1a & 37.048 & 116.119 & 4,304 & 957 & 562 & 78 & 957 & $S$ & $\mathrm{AM}$ & Profile \\
\hline 370254116064201 & UE- $1 b$ & 37.048 & 116.112 & 4,273 & 1,254 & 701 & 76 & 1,254 & $\mathrm{~S}$ & $\mathrm{AM}$ & Periodic \\
\hline 370253116055201 & UE- $1 \mathrm{c}$ & 37.048 & 116.099 & 4,207 & 1,880 & 1,772 & 74 & 1,880 & $\mathrm{C}$ & $\mathrm{AM}$ & Periodic \\
\hline 370005116040301 & UE- $1 \mathrm{~h}$ & 37.001 & 116.068 & 3,995 & 3,358 & 3,228 & 2,134 & 3,358 & $\mathrm{C}$ & $\mathrm{AM}$ & Profile \\
\hline 370254116082002 & UE- 1L (recompleted) & 37.048 & 116.140 & 4,457 & 5,339 & 2,284 & 716 & 2,284 & $\mathrm{~S}$ & $\mathrm{AM}$ & Periodic \\
\hline 370337116033002 & UE- 1q (2600 ft) & 37.060 & 116.059 & 4,081 & 2,600 & 2,600 & 2,459 & 2,600 & $\mathrm{C}$ & $\mathrm{AM}$ & Profile \\
\hline 370831116080701 & UE- 2ce & 37.142 & 116.136 & 4,765 & 1,650 & 1,505 & 1,377 & 1,650 & $\mathrm{C}$ & $\mathrm{AM}$ & Periodic \\
\hline 370411116025910 & UE- 3e 4-1 (2181ft) & 37.070 & 116.051 & 4,081 & 2,300 & 2,181 & 2,094 & 2,192 & $\mathrm{~V}$ & $\mathrm{AM}$ & Periodic \\
\hline 370411116025911 & UE- 3e 4-2 (1919ft) & 37.070 & 116.051 & 4,081 & 2,300 & 1,919 & 1,832 & 1,926 & $\mathrm{~V}$ & $\mathrm{AM}$ & Profile \\
\hline 370411116025912 & UE- 3e 4-3 (1661 ft) & 37.070 & 116.051 & 4,081 & 2,300 & 1,661 & 1,540 & 1,668 & $\mathrm{~V}$ & $\mathrm{AM}$ & Periodic \\
\hline 370556116025405 & UE- 4t 1 (1906-2010 ft) & 37.099 & 116.049 & 4,141 & 2,413 & 1,993 & 1,906 & 2,010 & $\mathrm{~V}$ & $\mathrm{AM}$ & Profile \\
\hline 370556116025406 & UE- 4t 2 (1564-1754 ft) & 37.099 & 116.049 & 4,141 & 2,413 & 1,724 & 1,564 & 1,754 & $\mathrm{~V}$ & $\mathrm{AM}$ & Profile \\
\hline 364915115574101 & UE- $5 n$ & 36.821 & 115.962 & 3,113 & 1,687 & 1,523 & 82 & 1,460 & $\mathrm{~F}$ & $\mathrm{AM}$ & Periodic \\
\hline 365905116033201 & UE- $6 \mathrm{~d}$ & 36.985 & 116.060 & 3,947 & 3,896 & 3,864 & 2,125 & 3,896 & $\mathrm{~F}$ & $\mathrm{AM}$ & Profile \\
\hline 365905116012002 & UE- 6e (2090-2230 ft) & 36.985 & 116.023 & 3,938 & 4,209 & 2,230 & 2,090 & 2,230 & $\mathrm{~V}$ & $\mathrm{AM}$ & Profile \\
\hline
\end{tabular}


Table 1. Characteristics of ground-water temperature data-collection sites at and in the vicinity of the Nevada Test Site, Nye, Clark, and Lincoln Counties, Nevada.-Continued

\begin{tabular}{|c|c|c|c|c|c|c|c|c|c|c|c|}
\hline \multirow[b]{2}{*}{$\begin{array}{c}\text { USGS site } \\
\text { identification No. }\end{array}$} & \multirow[b]{2}{*}{$\begin{array}{l}\text { USGS local } \\
\text { site name }\end{array}$} & \multirow[b]{2}{*}{ Latitude } & \multirow[b]{2}{*}{ Longitude } & \multirow{2}{*}{$\begin{array}{l}\text { Land- } \\
\text { surface } \\
\text { altitude }\end{array}$} & \multirow[b]{2}{*}{$\begin{array}{l}\text { Depth } \\
\text { drilled }\end{array}$} & \multirow[b]{2}{*}{$\begin{array}{l}\text { Well } \\
\text { depth }\end{array}$} & \multicolumn{2}{|c|}{ Open interval } & \multirow{2}{*}{$\begin{array}{c}\text { Hydro- } \\
\text { geologic } \\
\text { unit }\end{array}$} & \multirow{2}{*}{$\begin{array}{c}\text { Ground- } \\
\text { water flow } \\
\text { system or } \\
\text { subbasin }\end{array}$} & \multirow{2}{*}{$\begin{array}{c}\text { Available } \\
\text { ground-wate } \\
\text { temperature } \\
\text { data }\end{array}$} \\
\hline & & & & & & & $\begin{array}{l}\text { Depth to } \\
\text { top }\end{array}$ & $\begin{array}{c}\text { Depth to } \\
\text { bottom }\end{array}$ & & & \\
\hline 370556116000901 & UE- $7 \mathrm{nS}$ & 37.099 & 116.003 & 4,367 & 2,205 & 2,022 & 1,707 & 2,205 & $\mathrm{C}$ & AM & Periodic \\
\hline 371108116045303 & UE-10j (2232-2297 ft) & 37.185 & 116.082 & 4,574 & 2,613 & 2,532 & 2,232 & 2,297 & $\mathrm{C}$ & $\mathrm{AM}$ & Profile \\
\hline 371332116112802 & UE-12t $6(1461 \mathrm{ft})$ & 37.225 & 116.192 & 6,907 & 1,461 & 1,461 & 23 & 1,461 & $\mathrm{~V}$ & $\mathrm{AM}$ & Periodic \\
\hline 365550116091101 & UE-14b & 36.931 & 116.154 & 4,353 & 3,680 & 3,680 & 2,051 & 3,680 & $\mathrm{~V}$ & $\mathrm{AM}$ & Profile \\
\hline 370208116092402 & UE-16f (1479ft) & 37.036 & 116.158 & 4,651 & 1,479 & 1,409 & 1,293 & 1,479 & $\mathrm{~S}$ & $\mathrm{AM}$ & Profile \\
\hline 370425116095801 & UE-17a & 37.074 & 116.167 & 4,697 & 1,214 & 1,207 & 745 & 1,214 & $\mathrm{~S}$ & $\mathrm{AM}$ & Profile \\
\hline 370806116264001 & UE-18r & 37.135 & 116.446 & 5,538 & 5,004 & 2,183 & 1,629 & 5,004 & $\mathrm{~V}$ & AFFCR & Profile \\
\hline 370741116194501 & UE-18t & 37.128 & 116.330 & 5,201 & 2,600 & 2,600 & 120 & 2,600 & $\mathrm{~V}$ & AFFCR & Periodic \\
\hline 371608116191002 & UE-19c WW & 37.269 & 116.320 & 7,033 & 8,489 & 2,493 & 2,421 & 8,489 & V & AFFCR & Periodic \\
\hline 372034116222504 & UE-19h (recompleted) & 37.343 & 116.374 & 6,780 & 3,705 & 2,288 & 2,050 & 2,287 & $\mathrm{~V}$ & AFFCR & Profile \\
\hline 371442116243301 & UE-20bh 1 & 37.245 & 116.410 & 6,637 & 2,810 & 2,810 & 1,941 & 2,810 & $\mathrm{~V}$ & AFFCR & Profile \\
\hline 371425116251902 & UE-20n 1 (2834 ft) & 37.240 & 116.423 & 6,461 & 3,300 & 2,834 & 2,308 & 2,834 & $\mathrm{~V}$ & AFFCR & Periodic \\
\hline 363045115280201 & USAF Alpha 2 & 36.512 & 115.468 & 3,066 & 200 & 200 & 165 & 195 & - & $\mathrm{AM}$ & Periodic \\
\hline 363135115281401 & USAF Alpha 3 & 36.526 & 115.471 & 3,057 & 210 & 210 & 155 & 205 & - & $\mathrm{AM}$ & Periodic \\
\hline 363529115392101 & USAF MW-20 & 36.591 & 115.657 & 3,093 & 65 & 65 & 35 & 65 & - & $\mathrm{AM}$ & Periodic \\
\hline 363529115391301 & USAF MW-21 & 36.591 & 115.654 & 3,095 & 76 & 75 & 45 & 75 & - & $\mathrm{AM}$ & Periodic \\
\hline 363508115391701 & USAF MW-22 & 36.586 & 115.656 & 3,100 & 65 & 65 & 35 & 65 & - & $\mathrm{AM}$ & Periodic \\
\hline 363447115404601 & USAF Well 106-2 & 36.580 & 115.681 & 3,085 & 604 & 604 & 133 & 418 & - & $\mathrm{AM}$ & Periodic \\
\hline 363205115335601 & USAF Well 2278-1 & 36.535 & 115.567 & 3,200 & 400 & 353 & 240 & 353 & - & $\mathrm{AM}$ & Periodic \\
\hline 362830115270501 & USAF Well 2372-1 & 36.475 & 115.450 & 3,180 & 300 & 300 & - & - & - & $\mathrm{AM}$ & Periodic \\
\hline 363452115405101 & USAF Well 3 & 36.580 & 115.682 & 3,130 & 600 & 600 & 210 & 600 & - & $\mathrm{AM}$ & Periodic \\
\hline 370840116510101 & USBLM TPJ-1 & 37.145 & 116.851 & 3,991 & 107 & 107 & - & - & - & DTVSU & Periodic \\
\hline 363332115244001 & USFWS DR-1 & 36.558 & 115.411 & 3,579 & 957 & 930 & 870 & 930 & $\mathrm{C}$ & $\mathrm{AM}$ & Periodic \\
\hline 363212115240301 & USFWS SBH-1 & 36.537 & 115.402 & 3,475 & 720 & 720 & 665 & 695 & - & $\mathrm{AM}$ & Periodic \\
\hline 363407115215301 & USGS - Cow Camp & 36.569 & 115.366 & 4,175 & 1,403 & 1,403 & - & - & - & $\mathrm{AM}$ & Periodic \\
\hline 365502115134101 & USGS DDL-2 & 36.917 & 115.229 & 3,288 & 460 & 460 & 13 & 460 & $\mathrm{C}$ & $\mathrm{AM}$ & Periodic \\
\hline 370958116051512 & WW- 2 (3422 ft) & 37.166 & 116.088 & 4,470 & 3,422 & 3,422 & 2,700 & 3,412 & $\mathrm{C}$ & $\mathrm{AM}$ & Profile \\
\hline 365942116032901 & WW- 3 (1800 ft) & 36.995 & 116.059 & 3,969 & 1,800 & 1,800 & 1,209 & 1,800 & $\mathrm{~F}$ & $\mathrm{AM}$ & Profile \\
\hline 365418116012601 & WW- 4 & 36.905 & 116.025 & 3,602 & 1,479 & 1,438 & 115 & 1,479 & $\mathrm{~V}$ & $\mathrm{AM}$ & Periodic \\
\hline 365412116013901 & WW- 4A & 36.903 & 116.028 & 3,606 & 1,517 & 1,502 & 536 & 1,517 & V & $\mathrm{AM}$ & Periodic \\
\hline 364635115572901 & WW- 5A & 36.776 & 115.959 & 3,093 & 910 & 910 & 642 & 910 & $\mathrm{~F}$ & $\mathrm{AM}$ & Profile \\
\hline 364805115580801 & WW- 5B & 36.801 & 115.970 & 3,092 & 900 & 900 & 700 & 900 & $\mathrm{~F}$ & $\mathrm{AM}$ & Periodic \\
\hline 370142116021101 & WW- A (1870 ft) & 37.037 & 116.037 & 4,006 & 1,870 & 1,870 & 1,555 & 1,870 & $\mathrm{~F}$ & $\mathrm{AM}$ & Periodic \\
\hline
\end{tabular}


This page is intentionally left blank. 


\section{Appendix A. Periodic Ground-Water Temperature Data, Nevada Test Site and Vicinity, 2000-2006}

Data from periodic ground-water temperature measurements in 166 wells at and in the vicinity of the NTS are presented in a Microsoft ${ }^{\circledR}$ Excel spreadsheet. The spreadsheet provides information on site location, well construction, hydrogeologic unit, depths-to-water, and temperature data for these wells. Appendix A data are available for download at URL:

http://pubs.water.usgs.gov/ds269/. 
This page is intentionally left blank. 


\section{Appendix B. Ground-Water Temperature Profile Data, Nevada Test Site and Vicinity, 2004-2005}

Data from ground-water temperature profile measurements in 73 wells at and in the vicinity of the NTS are presented in a Microsoft ${ }^{\circledR}$ Excel spreadsheet. The spreadsheet provides information on site location, well construction, hydrogeologic unit, depths-to-water, and temperature data for these wells. Two graphs of temperature versus depth below land surface for each well with temperature profiles greater than 50 feet are also presented in appendix B. The scale chosen for one of these graphs is customized for each well to illustrate detailed changes in temperature with depth. The scale chosen for the other graph is standardized for all wells to illustrate the relative temperature profile length and change in temperature at each well when compared to all collected temperature profiles. Data are available for download at URL:

http://pubs.water.usgs.gov/ds269/. 
This page is intentionally left blank. 
For more information contact:

Director, Nevada Water Science Center

U.S. Geological Survey

2730 N. Deer Run Road

Carson City, Nevada 89701

http://nevada.usgs.gov 


$$
\text { ख़ }
$$

임.

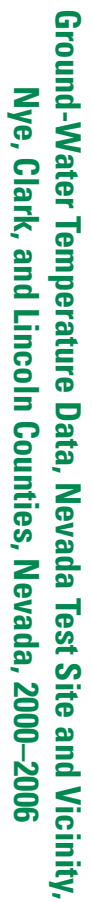

怘

) 